Available online at

INSECTA

Integrative Science Education and Teaching Activity Journal

Journal homepage : https://jurnal.iainponorogo.ac.id/index.php/insecta

\title{
$\longrightarrow$ Research Article \\ Comparison of Science Learning Outcome Between Using and Do Not Using Picture Media on State Islamic Elementary Students
}

\author{
Kurnia Hidayati \\ Institut Agama Islam Negeri (IAIN), Ponorogo, Indonesia \\ *Corresponding Address: kurniahidayati@gmail.com
}

\section{Article Information}

Article history:

Received: June 23, 2020

Accepted: June 27, 2020

Published: June 27, 2020

\section{Key Words}

Learning Outcome, Picture media

\begin{abstract}
Everything that has been achieved by students after conducting learning activities is called learning outcomes. In learning science at the elementary school level,needed media to improve learning outcomes. One of the media that can be used is picture media which are considered easy to make and inexpensive. This study uses quantitative methods with quasi-experimental designs consisting of experimental and control groups. Based on the calculation of the $t$ test of science learning outcomes of state Islamic elementary students between those who use and do not use picture media, the value of tcount is 14.527 and t-table is 2.05 at the significance level of $5 \%$. From the two values it is known that $\mathrm{t}$-count $>\mathrm{t}$-table, then Ho is rejected or $\mathrm{Ha}$ is accepted, so there is a difference in the learning outcomes of third grade of state Islamic elementary students between those who use and do not use picture media.
\end{abstract}

Kata Kunci:
Hasil belajar IPA, Media
gambar

Kata Kunci: gambar

\begin{abstract}
ABSTRAK
Segala sesuatu yang telah dicapai oleh peserta didik setelah melakukan kegiatan belajar disebut hasil belajar. Dalam pembelajaran IPA di tingkat SD/MI diperlukan penggunaan media untuk meningkatakan hasil belajar. Salah satu media yang bisa digunakan adalah media gambar yang dianggap mudah dibuat dan tidak mahal. Penelitian ini menggunakan metode kuantitatif dengan desain eksperimen semu yang terdiri dari kelompok eksperimen dan kontrol. Berdasarkan penghitungan uji t hasil belajar IPA siswa madrasah ibtidaiyah antara yang menggunakan dan tidak menggunakan media gambar diperoleh nilai $t_{\text {hitung }}$ sebesar 14,527 dan $t_{\text {tabel }}=2,05$ pada taraf signifikansi 5\%. Dari kedua nilai diketahui bahwa $t_{\text {hitung }}>t_{\text {tabel }}$, maka Ho ditolak atau Ha diterima, sehingga terdapat perbedaan hasil belajar IPA siswa madrasah
\end{abstract}


ibtidaiyah antara yang menggunakan dan tidak menggunakan media gambar.

() 2020 Kurnia Hidayati.

\section{PENDAHULUAN}

Belajar adalah serangkaian kegiatan jiwa raga untuk memperoleh sesuatu perubahan tingkah laku sebagai hasil dari pengalaman individu dalam interaksi dengan lingkungan yang menyangkut kognitif, afektif, dan psikomotor (Syaiful, 2014). Aktivitas belajar merupakan inti dari proses pendidikan di sekolah. Belajar merupakan alat utama bagi peserta didik dalam mencapai tujuan pembelajaran sebagai proses pendidikan di sekolah (Hadis \& Nurhayati, 2006). Dalam mewujudkan suasana belajar dan proses pembelajaran yang kondusif dan efektif, diperlukan suatu komunikasi atau interaksi edukatif. Interaksi ini berlangsung dalam proses belajar mengajar. Di dalam proses tersebut guru, murid, bahan ajar, serta media pembelajaran merupakan unsur yang saling berkaitan, mempengaruhi serta saling menunjang antara satu dengan yang lainnya (Hamid, 2016).

IPA atau ilmu kealaman adalah dunia zat, baik makhluk hidup maupun benda mati yang diamati (Trianto, 2010). IPA didefinisikan sebagai sekumpulan pengetahuan tentang objek dan fenomena alam yang diperoleh dari hasil pemikiran dan penyelidikan ilmuwan yang dilakukan dengan keterampilan bereksperimen dengan menggunakan metode ilmiah. Definisi ini memberi pengertian bahwa IPA merupakan cabang pengetahuan yang dibangun berdasarkan pengamatan dan klasifikasi data, dan biasanya disusun dan diverifikasi dalam hukum-hukum yang bersifat kuantitatif, yang melibatkan aplikasi penalaran matematis dan analisis data terhadap gejala-gejala alam. Dengan demikian, pada hakikatnya IPA meliputi tiga cakupan yaitu IPA sebagai produk, IPA sebagai proses dan IPA sebagai sarana pengembangan sikap ilmiah.

Sebagai ilmu pengetahuan, IPA juga mempunyai ciri khusus sebagaimana ilmu pengetahuan yang lain. Ciri-ciri khusus tersebut dipaparkan berikut ini. IPA mempunyai nilai ilmiah artinya kebenaran dalam IPA dapat dibuktikan lagi oleh semua orang dengan menggunakan metode ilmiah dan prosedur seperti yang dilakukan terdahulu oleh penemunya. Selain itu IPA juga merupakan suatu kumpulan pengetahuan yang tersusun secara sistematis, dan dalam penggunaannya secara umum terbatas pada gejala-gejala alam. Perkembangan IPA selanjutnya tidak hanya ditandai oleh adanya kumpulan fakta saja, tetapi juga ditandai oleh munculnya "metode ilmiah" (scientific methods) yang terwujud melalui suatu rangkaian "kerja ilmiah" (working scientifically), nilai dan "sikap ilmiah" (scientific attitudes) (Astuti et al., 2016).

IPA adalah pelajaran yang memberikan ilmu pengetahuan tentang alam. Dalam ilmu pengetahuan tentang alam yang dipelajari adalah tentang benda atau fenomena yang ada di sekitar kita. Hal itu kadang sulit dibayangkan dengan angan-angan atau mungkin setiap orang memiliki pandangan tersendiri. Sehingga nantinya sulit untuk membuat presepsi yang sama pada setiap individu yang mempelajarinya sehingga dibutuhkan sebuah alat untuk dapat membuat presepsi yang sama yaitu dengan gambar atau foto. Foto menghadirkan ilustrasi melalui gambar yang hampir menyamai dari suatu obyek atau situasi (Arsyad, 2013). Dengan begitu semua akan memiliki pemikiran yang sama dengan terbentuk pemikiran dari gambar yang ditunjukkan oleh media. Semakin banyak alat indra yang digunakan untuk menerima dan mengelola informasi semakin besar kemungkinan informasi tersebut dimengerti dan dapat dipertahankan dalam ingatan (Arsyad, 2013). Sehingga dengan menggunakan media gambar dan mendapat penjelasan dari guru siswa telah menggunakan dua indra yaitu indra penglihatan dan pendengaran sehingga ilmu yang 
disampaikan dalam pembelajaran IPA akan semakin besar kemungkinannya untuk dimengerti dan diingat oleh siswa.

Media pada dasarnya adalah "bahasa guru" artinya dalam proses penyampaian pesan pembelajaran, guru harus pandai memilih "bahasa apa" yang paling mudah dimengerti dan dipahami siswanya (Komsiyah, 2012). Media merupakan alat bantu guru dalam melaksanakan pembelajaran dan berfungsi sebagai sarana untuk menyampaikan pesan dari guru kepada siswa. Jika digunakan secara benar, media pembelajaran dapat memperlancar interaksi guru dan siswa, siswa dan siswa, serta siswa dan sumber belajar. Media yang digunakan dalam pembelajaran banyak ragamnya (Komsiyah, 2012).

Belajar dengan cara melihat cirinya adalah lirikan ke atas bila berbicara, berbicara dengan cepat. Bagi siswa yang bergaya belajar visual, yang memegang peranan penting adalah mata/penglihatan (visual). Dalam gaya belajar visual adapun ciri-cirinya adalah bicara agak cepat, mementingkan penampilan dalam berpakaian/presentasi, tidak mudah terganggu oleh keributan, mengingat apa yang dilihat dari pada yang didengar, lebih suka membaca dari pada dibacakan, pembaca cepat dan tekun, sering menegtahui apa yang harus dikatakan, tetapi tidak pandai memilih kata-kata, lebih suka melakukan demonstrasi dapi pada pidato, lebih suka musik dari pada seni, mempunyai masalah untuk mengingat instruksi verbal kecuali bila ditulis, dan sering minta bantuan orang untuk mengulangnya (Thobroni, n.d.). Dalam hal tersebut maka yang dimaksud dalam bahasa guru adalah media yang mempermudah guru untuk menyampaikan pelajaran.

Kegiatan belajar mengajar di kelas merupakan suatu komunikasi antara guru dengan siswa-siswinya untuk bertukar pikiran dalam mengembangkan ide maupun pengertian. Dalam komunikasi sendiri sering terjadi penyimpangan-penyimpangan sehingga komunikasi tersebut tidak efektif dan efisien. Salah satu cara yang dapat digunakan untuk mengatasi keadaan masalah tersebut ialah penggunaan media secara terintegrasi dalam proses belajar mengajar, karena dalam fungsi media dalam kegiatan tersebut sebagai penyaji stimulus informasi, sikap serta untuk meningkatkan keserasian dalam penerimaan informasi(Asnawir \& Usman, 2002). Sehingga situasi pembelajaran menjadi sangat baik dan sangat kondusif untuk tercapainya tujuan pembelajaran dikarenakan penggunaan media yang serasi sehingga menstimulus siswa untuk belajar lebih baik dan nantinya hasil belajar yang diharapkan akan tercapai dengan baik.

Dalam sebuah pembelajaran yang dilakukan di MI haruslah dapat menarik perhatian dari siswa dikarenakan siswa usai MI sangatlah aktif. Siswa yang aktif tentulah agak sulit untuk membawanya pada fokus tertentu secara lama terutama pada pelajaran yang dianggapnya kurang menarik. Maka dari itu guru sebagai pembimbing dalam pembelajaran haruslah dapat menguasai kelas dan membuat siswa dapat fokus pada pelajaran sehingga hasil belajar yang didapat dapat bisa maksimal. Akan tetapi membuat pembelajaran tersebut tidaklah mudah. Guru harus memikirkan sesuatu hal yang dapat menarik siswa fokus siswa pada pembelajaran.

Pada saat ini pembelajaran yang berpusat pada guru sudah dianggap tidak efektif, apalagi sistem pembelajaran dengan sikap guru yang keras. Siswa lebih menginginkan guru yang bersahabat dan dapat membimbing para siswanya untuk memahami pelajaran guna untuk mendapatkan hasil belajar yang baik. Guna untuk mensukseskan pembelajaran seperti di atas maka guru harus berusaha mencari sistem pembelajaran yang sesuai dengan yang dinginkan siswa dan tetap memperhatikan proses dan hasil belajar, maka dari itu guru bisa mengguakan media untuk mendukung proses pembelajaran. Dalam pembelajaran IPA media yang dianggap mudah didapat dan tidak menarik banyak biaya maka mempermudah guru untuk menggunakan media gambar untuk mendukung proses pembelajaran sehingga hasil belajar baik. Penelitian ini dilakukan untuk melihat ada tidaknya perbedaan hasil belajar siswa yang menggunakan dan tidak menggunakan media gambar. 
Belajar dapat didefinisikan sebagai suatu proses usaha yang dilakukan seseorang untuk memperoleh suatu perubahan tingkah laku yang baru secara keseluruhan sebagai hasil pengalamannya sendiri dalam interaksi dengan lingkungannya (Alfabeta, 2003). Hal tersebut senada dengan pendapat yang mengartikan belajar sebagai proses perubahan perilaku, akibat interaksi individu dengan lingkungan (Ali, 2009). Sedangkan pendapat lain mengemukakan bahwa belajar sebagai suatu perubahan yang relatif permanen dalam suatu kecenderungan tingkah laku sebagai hasil dari praktek atau latihan (Sudjana, 1990).

Perubahan yang terjadi dalam diri seseorang banyak sekali sifat maupun jenisnya, karena itu tidak setiap perubahan dalam diri seseorang merupakan perubahan dalam arti belajar. Ciri-ciri perubahan tingkah laku dalam pengertian belajar menurut Slameto adalah perubahan terjadi secara sadar; perubahan dalam belajar terjadi secara kontinu dan fungsional; perubahan dalam belajar terjadi bersifat positif dan aktif; perubahan dalam belajar bukan bersifat sementara; perubahan dalam belajar bertujuan atau terarah; dan perubahan mencakup seluruh aspek tingkah laku. Perubahan tingkah laku yang terjadi tersebut timbul secara sadar akibat praktek, pengalaman dan latihan, bukan secara kebetulan (Alfabeta, 2003).

Dari beberapa definisi mengenai belajar di atas dapat disimpulkan bahwa belajar merupakan suatu usaha untuk mencapai tujuan tertentu, yaitu untuk mendapatkan perubahan tingkah laku. Perubahan tingkah laku tersebut dapat terjadi akibat pengalaman, praktek atau latihan dan interaksi individu dengan lingkungan, perubahan yang terjadi tersebut harus berlangsung secara sadar. Apa yang telah dicapai oleh peserta didik setelah melakukan kegiatan belajar sering disebut prestasi belajar, ada juga yang menyebutnya dengan hasil belajar yang merujuk pada aspek kognitif, afektif, dan psikomotorik (Tohirin, 2005).Hal serupa dikemukakan oleh Kingsley dalam (Sudjana, 1990) terdapat tiga macam hasil belajar, yakni: keterampilan dan kebiasaan, pengetahuan dan pengertian serta sikap dan citacita. Hasil bisa diartikan sebagai suatu kegiatan yang telah dikerjakan dan diciptakan, baik secara individu maupun kelompok (Syaiful, 2014).

Selanjutnya terkait media pembelajaran, kata "media" berasal dari bahasa latin dan merupakan bentuk jamak dari kata "medium", yang secara harfiah berarti "perantara atau pengantar". Dengan demikian media merupakan wahana penyalur informasi belajar atau penyalur pesan (Syaiful, 2014). Media merupakan sesuatu yang bersifat menyalurkan pesan dan dapat merangsang pikiran, perasaan, dan kemauan siswa sehingga dapat mendorong terjadinya proses belajar pada dirinya. Penggunaan media secara kreatif akan memungkinkan siswa untuk belajar lebih baik dan dapat meningkatkan performan mereka sesuai dengan tujuan yang ingin dicapai (Arsyad, 2013).

Proses pembelajaran merupakan proses komunikasi. Dalam suatu proses komunikasi selalu melibatkan tiga komponen pokok, yaitu komponen pengirim pesan (guru), komponen penerima pesan (siswa), dan komponen pesan itu sendiri yang biasanya berupa materi pelajaran. Kadang-kadang dalam proses pembelajaran terjadi kegagalan komunikasi. Artinya, materi pelajaran atau pesan yang disampaikan guru tidak dapat diterima oleh siswa dengan optimal, artinya tidak seluruh materi pelajaran dapat dipahami dengan baik oleh siswa. Untuk menghindari itu semua, maka guru dapat menyusun suatu kegiatan pembelajaran dengan memanfaatkan berbagai media pembelajaran (Sanjaya, 2019).

Saat peserta didik melakukan kegiatan pembelajaran, siswa tidak akan pernah sepi dari aktivitas. Tidak pernah terlihat yang helajar tanpa melibatkan aktivitas raganya. Apalagi itu berhubungan dengan menulis, mencatat, memandang, membaca, mengingat, berpikir, latihan, atau praktik dan sebagainya (Syaiful, 2014). Kemampuan dalam memahami suatu pelajaran pun juga berbeda. Media pembelajaran dapat memperjelas penyajian pesan dan informasi sehingga dapat memperlancar dan meningkatkan proses dan hasil belajar (Arsyad, 
2013). Penggunaan media dalam pembelajaran adalah suatu hal yang penting untuk membantu guru untuk menyampaikan pesan dari pelajaran yang diajarkan.

Media berfungsi untuk tujuan instruksi di mana informasi yang terdapat dalam media itu harus melibatkan siswa baik dalam benak atau mental maupun dalam bentuk aktivitas yang nyata sehingga pembelajaran dapat terjadi (Arsyad, 2013). Media sebagai alat bantu dalam pembelajaran juga memiliki fungsi, antara lain: membantu mempermudah belajar bagi siswa dan membantu memudahkan mengajar bagi guru, memberikan pengalaman lebih nyata (yang abstrak menjadi lebih konkrit), menarik perhatian dan minat siswa untuk belajar, semua indera siswa dapat diaktifkan dan dapat membangkitkan dunia teori dengan realitanya (Asnawir \& Usman, 2002).

Media gambar adalah foto atau sejenisnya yang menampakkan benda yang banyak dan umum digunakan, mudah dimengerti dan dinikmati dalam pembelajaran, serta untuk mengatasi kesulitan menampilkan benda aslinya di dalam kelas (Asnawir \& Usman, 2002). Media gambar adalah media yang menampilkan gambar seperti foto, lukisan, dan gambar yang menyerupai aslinya sehingga tidak terjadi salah presepsi dalam penjelasan media gambar dengan aslinya.

Pemanfaatan media gambar berarti mengusahakan media gambar dapat digunakan dalam proses pembelajaran. Kemampuan media gambar dalam pembelajaran dapat merangsang minat dan perhatian siswa, sehingga membantu siswa dalam memahami dan mengingat isi informasi bahan dalam pembelajaran yang menyertainya. Beberapa kelebihan media gambar adalah: sifatnya konkrit, lebih realistis menunjukkan pokok masalah dibanding dengan media verbal semata; dapat mengatasai masalah batasan ruang dan waktu; dapat memperjelas suatu masalah, dalam bidang apa saja dan untuk tingkat usia beberapa saja, sehingga dapat mencegah atau membetulkan kesalahpahaman; murah harganya, mudah didapat, mudah digunakan, tanpa memerlukan peralatan yang khusus (Arsyad, 2013).

Ilmu pengetahuan alam atau sains (science) berasal dari bahasa latin scientia yang arti harfiahnya pengetahuan tetapi berkembang menjadi khusus IPA (sains). Sains sebagai proses merupakan langkah-langkah yang ditempuh para ilmuan untuk melakukan penyelidikan dalam rangka mencari penjelasan tentang gejala-gejala alam (Astuti et al., 2016). IPA sebagai pemupuk sikap, di dalam konteks pengajaran IPA, sikap dibatasi pengertiannya pada sikap ilmiah terhadap alam sekitar. Sikap ilmiah ini dapat dikembangkan pada anak- anak usia SD/MI adalah: sikap ingin tahu, sikap kerja sama, sikap ingin mendapatkan sesuatu yang baru, sikap tidak putus asa, sikap tidak berprasangka, sikap mawas diri, sikap bertanggung jawab, sikap berpikir bebas, sikap disiplin diri, sikap ilmiah tersebut dapat dikembangkan tatkala peserta didik melakukan diskusi, percobaan, simulasi, atau kegiatan observasi lapangan (Sugianto, 2009).

Pada hakikatnya IPA dapat ditinjau dari tiga segi, yaitu: IPA sebagai produk merupakan informasi tentang semesta yang merupakan hasil temuan-temuan para ahli berupa fakta, konsep, prinsip, hukum, dan teori; makna IPA sebagai proses adalah proses untuk mendapatkan IPA yang dilakukan melalui metode ilmiah. Pada anak-anak usia SD/MI, metode ilmiah dikembangkan secara bertahap, kesinambungan, dan harapan bahwa pada akhirnya akan terbentuk paduan yang lebih utuh, sehingga harapannya anak-anak SD/MI mampu melakukan penelitian secara sederhana. Pentahapan pengembangannya disesuaikan dengan tahapan metode ilmiah; Di dalam konteks pengajaran IPA sikap dibatasi pengertiannya pada sikap ilmiah terhadap alam sekitar. Sikap ilmiah yang memungkinkan dapat dikembangkan pada anak-anak SD/MI adalah sikap ingin tahu dan sikap ingin mendapatkan (Sugianto, 2009).

Dalam pembelajaran IPA juga diatur tentang tujuan dari pembelajaran IPA oleh Menteri Pendidikan Nasional No. 24 Tahun 2006 dijelaskan, bahwa mata pelajaran IPA di SD/MI bertujuan agar siswa memiliki kemampuan: memperoleh keyakinan terhadap 
kebesaran Tuhan Yang Maha Esa berdasarkan keberadaan, keindahan, dan keteraturan alam ciptaanya; mengembangkan pengetahuan dan pemahaman konsep-konsep IPA yang bermanfaat dan dapat diterapkan dalam kehidupan sehari-hari; mengembangkan rasa ingin tahu, sikap positif dan kesadaran tentang adanya hubungan yang saling mempengaruhi antara IPA, lingkungan, teknologi dan masyarakat; mengembangkan keterampilan proses untuk menyelidiki alam sekitar, memecahkan masalah dan membuat keputusan; meningkatkan kesadaran untuk berperan serta dalam memelihara, menjaga dan melestarikan lingkungan alam; meningkatkan kesadaran untuk menghargai alam dan segala keteraturannya sebagai salah satu ciptaan Tuhan; memperoleh bekal pengetahuan, konsep dan ketrampilan IPA sebagai dasar untuk melanjutkan pendidikan ke SMP/MTs.

\section{METODE}

Penelitian ini menggunakan metode kuantitatif dengan desain eksperimen semu (quasi experimental design), yang merupakan pengembangan dari true experimental design yang sulit dilaksanakan (Sugiyono, n.d.). Desain ini menggunakan kelompok kontrol, tetapi tidak dapat berfungsi sepenuhnya untuk mengontrol variabel-variabel luar yang mempengaruhi pelaksanaan eksperimen. Eksperimen semu digunakan dalam penelitian ini karena melibatkan kelompok subyek utuh dalam eksperimen, yang secara alami sudah terbentuk dalam kelas daripada menentukan secara random untuk perlakuan eksperimen. Pada penelitian ini yang dibandingkan adalah hasil belajar siswa kelas tiga MIN Paju antara kelompok eksperimen yang menggunakan media gambar dan kelompok kontrol yang tidak menggunakan media gambar.

Populasi pada penelitian ini adalah siswa kelas III MIN Paju sebanyak 30 orang yang terbagi ke dalam 2 kelas rombongan belajar. Dari populasi yang ada, semua dijadikan sampel. Siswa kelas IIIa sebanyak 15 orang yang dijadikan kelas eksperimen dan siswa kelas IIIb sebanyak 15 orang yang dijadikan kelas kontrol. Jumlah sampel diambil berdasarkan pernyataan Creswell yang menyatakan bahwa jumlah sampel minimal untuk penelitian eksperimen adalah 15 subyek tiap kelompok (Creswell \& Creswell, 2017). Dalam penelitian ini, instrumen yang digunakan adalah hasil belajar IPA pada siswa kelas III di MIN Paju Ponorogo. Analisis data yang digunakan adalah dengan menghitung frekuensi dan uji t.

\section{HASIL DAN PEMBAHASAN}

\section{Hasil Belajar IPA Siswa Kelas III MIN Paju yang Menggunakan Media Gambar}

\begin{tabular}{ccc} 
Tabel 1. Hasil Belajar IPA Siswa Kelas III MIN Paju yang Menggunakan Media Gambar \\
\cline { 1 - 3 } Hasil Belajar Siswa & Frekuensi & Persentase \\
\hline 5 & 1 & 6,67 \\
6 & 0 & 0 \\
7 & 1 & 6,67 \\
8 & 4 & 26,67 \\
9 & 7 & 46,67 \\
10 & 2 & 13,33 \\
Jumlah & 15 & 100 \\
\hline
\end{tabular}

Dari tabel 1 di atas diketahui bahwa siswa yang memperoleh nilai 5 ada 1 orang $(6,67 \%)$, nilai 6 tidak ada (0\%), nilai 7 ada 1 orang $(6,67 \%)$, nilai 8 ada 4 orang $(26,67$ $\%)$, nilai 9 ada 7 orang $(46,67 \%)$ dan nilai 10 ada 2 orang $(13,33 \%)$. Data tersebut jika dibuat grafik akan tampak seperti berikut: 


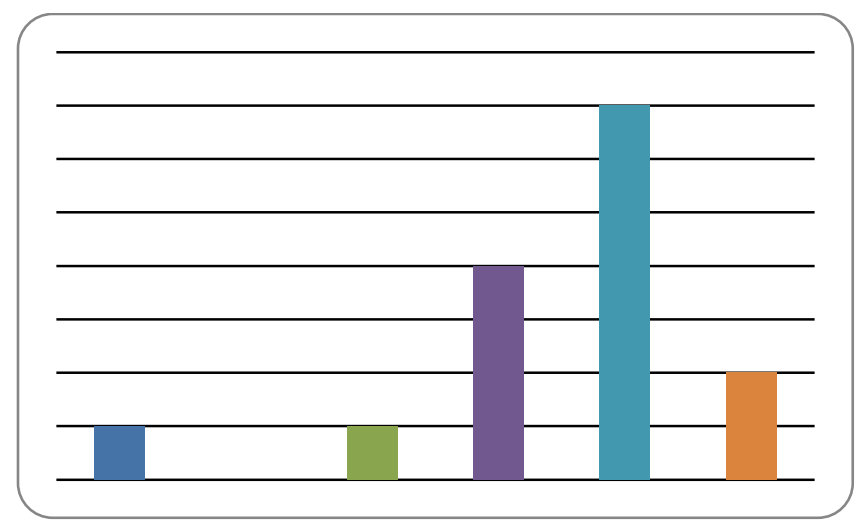

Gambar 1. Grafik Hasil Belajar IPA Siswa Kelas Tiga MIN Paju yang Menggunakan Media Gambar

\section{Hasil Belajar IPA Siswa Kelas III MIN Paju yang Tidak Menggunakan Media Gambar}

Tabel 2 Hasil Belajar IPA Siswa Kelas III MIN Paju yang Tidak Menggunakan Media

\begin{tabular}{ccc} 
& Gambar & \\
\hline Hasil Belajar Siswa & Frekuensi & Persentase \\
\hline 5 & 6 & 40 \\
6 & 3 & 20 \\
7 & 1 & 6,67 \\
8 & 2 & 13,33 \\
9 & 1 & 6,67 \\
10 & 2 & 13,33 \\
Jumlah & 15 & 100 \\
\hline
\end{tabular}

Dari tabel 2 di atas diketahui bahwa siswa yang memperoleh nilai 5 ada 6 orang (40 $\%$ ), nilai 6 ada 3 orang (20\%), nilai 7 ada 1 orang (6,67\%), nilai 8 ada 2 orang (13,33\%), nilai 9 ada 1 orang $(6,67 \%)$ dan nilai 10 ada 2 orang $(13,33 \%)$. Data tersebut jika dibuat grafik akan tampak seperti berikut:

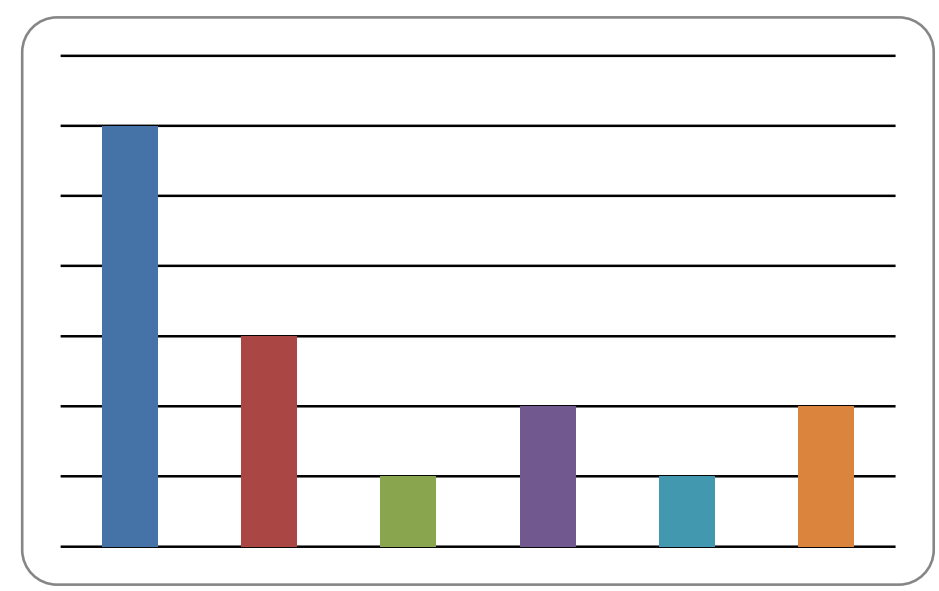

Gambar 2. Grafik Hasil Belajar IPA Siswa Kelas Tiga MIN Paju yang Tidak Menggunakan Media Gambar 


\section{Uji Beda Hasil Belajar IPA Siswa Kelas III MIN Paju antara yang Menggunakan dan Tidak Menggunakan Media Gambar}

Uji t dilakukan untuk mengetahui ada tidaknya perbedaan hasil belajar IPA siswa kelas III MIN Paju antara yang menggunakan dan tidak menggunakan media gambar. Uji tersebut dihitung berdasarkan data dari 30 orang siswa (masing-masing 15 orang). Berdasarkan penghitungan uji t hasil belajar IPA siswa kelas III MIN Paju antara yang menggunakan dan tidak menggunakan media gambar diperoleh nilai $t_{\text {hitung }}$ sebesar 14,527 dan $t_{\text {tabel }}=2,05$ pada taraf signifikansi 5\%. Dari kedua nilai diketahui bahwa $t_{\text {hitung }}>t_{\text {tabel }}$, maka Ho ditolak atau Ha diterima, sehingga terdapat perbedaan hasil belajar IPA siswa kelas tiga MIN Paju antara yang menggunakan dan tidak menggunakan media gambar.

\section{KESIMPULAN}

Berdasarkan penghitungan uji t hasil belajar IPA siswa kelas III MIN Paju antara yang menggunakan dan tidak menggunakan media gambar diperoleh nilai $t_{\text {hitung }}$ sebesar 14,527 dan $t_{\text {tabel }}=2,05$ pada taraf signifikansi 5\%. Dari kedua nilai diketahui bahwa $t_{\text {hitung }}>$ $\mathrm{t}_{\text {tabel}}$, maka Ho ditolak atau Ha diterima, sehingga terdapat perbedaan hasil belajar IPA siswa kelas III MIN Paju antara yang menggunakan dan tidak menggunakan media gambar.

\section{REFERENSI}

Alfabeta, S. (2003). Belajar dan Faktor-faktor yang Mempengaruhinya. Jakarta. PT. Rineka Cipta.

Ali, M. (2009). Pengembangan media pembelajaran interaktif mata kuliah medan elektromagnetik. Jurnal Edukasi Elektro, 5(1).

Arsyad, A. (2013). Media Pembelajaran; Edisi Revisi.

Asnawir, B. U., \& Usman, M. B. (2002). Media pembelajaran. Jakarta: Ciputat Pers.

Astuti, R., Sunarno, W., \& Sudarisman, S. (2016). Pembelajaran IPA dengan pendekatan ketrampilan proses sains menggunakan metode eksperimen bebas termodifikasi dan eksperimen terbimbing ditinjau dari sikap ilmiah dan motivasi belajar siswa. Proceeding Biology Education Conference: Biology, Science, Enviromental, and Learning, 13(1), 338-345.

Creswell, J. W., \& Creswell, J. D. (2017). Research design: Qualitative, quantitative, and mixed methods approaches. Sage publications.

Hadis, A., \& Nurhayati, B. (2006). Psikologi dalam pendidikan. Bandung: Alfabeta.

Hamid, A. (2016). Penerapan Strategi Pembelajaran STAD (Student Teams Achievment Division) untuk Meningkatkan Hasil Belajar Qawaid Nahwiyah Peserta Didik Kelas VIII di MTs Al-Khairiyah Kaliawi Bandar Lampung. Jurnal Al-Bayan: Jurnal Jurusan Pendidikan Bahasa Arab, 8(2), 17-32.

Komsiyah, I. (2012). Belajar dan pembelajaran. Yogyakarta: Teras.

Sudjana, N. (1990). Teori-teori belajar untuk pengajaran. Lembaga Penerbit Fakultas Ekonomi Universitas Indonesia.

Sugianto, A. (2009). Pembelajaran IPA MI. Surabaya: LAPIS-PGMI. 
Sugiyono, P. (n.d.). Dr. 2010. Metod. Penelit. Kuantitatif, Kualitatif, Dan R\&D. Bandung CV Alf.

Syaiful, B. (2014). Guru dan anak didik dalam interaksi edukatif. Rineka Cipta.

Thobroni, M. (n.d.). Mustofa, Arif. 2013. Belajar Dan Pembelajaran. Yogyakarta: Ar-Ruzz Media.

Tohirin. (2005). Psikologi pembelajaran pendidikan agama Islam: Berbasis intergrasi dan kompetensi. PT RajaGrafindo Persada.

Trianto, T. (2010). Model pembelajaran terpadu. Jakarta: Bumi Aksara. 